\title{
Flutamide as an Alternative Anti-androgen Agent and Predictor of the Efficacy of Novel Androgen Receptor-targeted Agents
}

\author{
NORIYA YAMAGUCHI ${ }^{1}$, SHUICHI MORIZANE ${ }^{1 *}$, TETSUYA YUMIOKA ${ }^{1}$, HIDETO IWAMOTO $^{1}$, \\ KATSUYA HIKITA ${ }^{1}$, TAKEHIRO SEJIMA ${ }^{2}$, MASASHI HONDA ${ }^{1}$ and ATSUSHI TAKENAKA ${ }^{1}$ \\ ${ }^{1}$ Division of Urology, Department of Surgery, Tottori University Faculty of Medicine, Yonago, Japan; \\ ${ }^{2}$ Department of Urology, Matsue City Hospital, Matsue, Japan
}

\begin{abstract}
Background/Aim: There are few reports that verify the relationship between the therapeutic effects of flutamide and novel androgen receptor-targeted agents. We aimed to evaluate the benefits of flutamide as an alternative anti-androgen agent and its effects on the efficacy of novel androgen receptortargeted agents. Patients and Methods: Patients with castrationresistant prostate cancer on novel androgen receptor-targeted agents without prior docetaxel therapy were included. Changes in prostate-specific antigen (PSA) level were recorded. Results: Patients who responded well to flutamide (Flutamide effective) following initial maximum androgen blockade (MAB) showed significantly higher changes in serum PSA levels $(p=0.039)$ and PSA-progression-free survival $(P F S)$ rate $(p=0.016)$ following enzalutamide therapy compared to those who did not respond well to flutamide. Multivariate analysis showed that the factor of Flutamide effective was significantly associated with a good PSA-PFS rate following enzalutamide therapy (HR=7.36, 95\%CI=1.4-38.71, $p=0.018)$. Conclusion: Patients showing good response to flutamide following initial MAB may achieve a satisfactory PSA-PFS rate with subsequent enzalutamide therapy.
\end{abstract}

Prostate cancer is the second leading cause of cancer-related deaths in western industrialized countries (1). Similarly, the number of prostate cancer patients is increasing in Japan (2). Patients with advanced prostate cancer with lymph node and/or distant organ metastasis typically receive hormone therapy, undergo medical or surgical castration, and/or receive antiandrogen agents, such as bicalutamide. However, most prostate cancers acquire resistance to initial hormone therapy and

Correspondence to: Shuichi Morizane, Division of Urology, Department of Surgery, Tottori University Faculty of Medicine, 86 Nishi-cho, Yonago 683-8503, Japan. Tel.: +81 859386607, Fax: +81 859386609, e-mail: morizane@med.tottori-u.ac.jp

Key Words: Alternative anti-androgen therapy, novel androgen receptor targeted agent, flutamide. progress to castration-resistant prostate cancer (CRPC) (3). As second-line therapy for CRPC, flutamide, is an alternative antiandrogen agent that has been frequently used in the past, however, the rate of use is gradually reducing following the introduction of novel anti-androgen receptor-targeted agents, such as enzalutamide and abiraterone acetate. These novel agents have demonstrated a significantly improved overall survival in randomized clinical trials targeting both docetaxelnaïve (PREVAIL and COU-AA 302 trials) and docetaxeltreated (AFFIRM and COU-AA 301 trials) CRPC patients (48). On the other hand, several previous studies have shown that alternative anti-androgen therapy exhibits a good response in patients following initial maximum androgen blockade (MAB) failure. Furthermore, patients having a good response to alternative anti-androgen therapy demonstrate a significantly better cancer-specific survival (CSS) rate compared to those without a good response to alternative anti-androgen therapy (9-11). There exist a few reports showing the effects of novel androgen receptor- targeted agents following anti-androgen therapy using flutamide $(12,13)$. In this study, we evaluated the clinical benefits of flutamide as an alternative anti-androgen agent and examined whether the therapeutic effects of flutamide affect the efficacy of novel androgen receptortargeted agents.

\section{Patients and Methods}

Patients and data collection. We reviewed the medical records of 79 patients who were diagnosed with castration-resistant prostate cancer and received therapy with novel androgen receptor-targeted agents (enzalutamide and abiraterone) between May 2014 and April 2016 in our hospital and in satellite hospitals. All patients received maximum androgen blockade (MAB) with bicalutamide as initial hormone therapy. The study protocol was approved by the institutional review board of the Tottori University Faculty of Medicine (Approval no. 1704A010).

We excluded 20 patients who were administered with docetaxel before induction with novel androgen receptor-targeted agent. We consequently analyzed 59 patients ( 37 received enzalutamide and 22 received abiraterone as the first novel androgen receptor-targeted agent). Of the 37 patients who received enzalutamide, 21 received 
Table I. Clinical characteristics of patients using novel androgen receptor targeted agents.

\begin{tabular}{|c|c|c|c|}
\hline & \multicolumn{2}{|c|}{ Novel androgen receptor-targeted agents } & \multirow[b]{2}{*}{$p$-Value } \\
\hline & Enzalutamide $(\mathrm{n}=37)$ & Abiraterone $(\mathrm{n}=22)$ & \\
\hline Median Age (years, range) & $75(58-88)$ & $70.0(47-88)$ & 0.147 \\
\hline Median initial PSA (ng/ml, range) & $211.8(5.3-14913.3)$ & $71.8(6.7-3648.5)$ & 0.379 \\
\hline Median PSA (novel androgen receptor-targeted agents induction (ng/ml, range) & $8.6(8.6-130.9)$ & $4.3(10.0-68.3)$ & 0.547 \\
\hline Biopsy Gleason score (n, \%) & & & 0.924 \\
\hline$\leq 7$ & $9(24.3)$ & $5(22.7)$ & \\
\hline $8-10$ & $23(62.2)$ & $15(68.2)$ & \\
\hline Unknown & $5(13.5)$ & $2(9.1)$ & \\
\hline Clinical T stage (n, \%) & - & & 0.081 \\
\hline $\mathrm{T} 1-\mathrm{T} 2$ & $4(10.8)$ & $7(31.8)$ & \\
\hline$\geq \mathrm{T} 3 \mathrm{a}$ & $33(89.2)$ & $15(68.2)$ & \\
\hline $\mathrm{N}$ positive (lymph node meta) (n, \%) & $14(37.8)$ & $8(36.4)$ & 0.785 \\
\hline M positive $(n, \%)$ & $24(64.9)$ & $16(72.7)$ & 1.000 \\
\hline Flutamide use (as second line MAB) $(n, \%)$ & $21(56.8)$ & $8(36.4)$ & 0.180 \\
\hline Flutamide effective (PSA decline compared to baseline of flutamide start) (n, \%) & $12 / 21(57.1)$ & $5 / 8(62.5)$ & 1.000 \\
\hline Median PSA nadir during initial MAB (ng/ml, range) & $0.31(0.0-39.9)$ & $0.22(0.01-152.4)$ & 0.527 \\
\hline Median duration of initial MAB (months, range) & $17.0(2.0-44.0)$ & $15.5(3.5-108.0)$ & 0.241 \\
\hline
\end{tabular}

PSA: Prostate-specific antigen; MAB: maximum androgen blockade.

and 16 did not receive alternative anti-androgen therapy with flutamide as a consequence to initial MAB with bicalutamide. Of the 22 patients who received abiraterone, 8 received and 14 did not receive alternative anti-androgen therapy with flutamide.

Definition of CRPC, flutamide effects, and PSA-PFS with novel androgen receptor-targeted agents. CRPC was defined as a consecutive rise in prostate-specific antigen (PSA) level one week apart, resulting in two $50 \%$ increases over the nadir, and a PSA level of $>2 \mathrm{ng} / \mathrm{ml}$ with serum testosterone $<50 \mathrm{ng} / \mathrm{dl}$ or radiological progression. The efficacy of flutamide was defined as any increase or decrease in the PSA level as compared to the baseline PSA level following flutamide induction. PSA progression with novel androgen receptor-targeted agents was defined as an increase in PSA level by $>25 \%$ as compared to the baseline or nadir PSA level following novel androgen receptor-targeted agent induction according to the Prostate Cancer Working Group 2 criteria (14). PSA-progression free survival (PSA-PFS) of initial novel androgen receptor-targeted agents (enzalutamide or abiraterone) was estimated from the baseline to the start of either novel androgen receptor-targeted agent until the time of PSA progression. CSS was defined as the time from the start of either novel androgen receptortargeted agent to death caused by prostate cancer.

Statistical analyses. Student $t$-test and $\chi^{2}$ test were used to compare the means and proportions. Log-rank test was used to compare the differences of PSA-PFS and CSS rate among patients showing good response to flutamide following initial MAB with bicalutamide (flutamide effective group), patients not responding to flutamide following initial MAB using bicalutamide (flutamide ineffective group), and patients who did not receive flutamide (flutamide no use group). Cox proportional hazards regression analysis was performed to identify the prognostic factors. All statistical analyses were performed using Easy R (EZR; Saitama Medical Center, Jichi Medical University, Saitama, Japan) (15). Significance was considered at $p<0.05$.

\section{Results}

The clinical characteristics of patients using novel androgen receptor-targeted agents are shown in Table I. No difference with regards to any parameter between patients who received enzalutamide and those who received abiraterone therapy was found (Table I). Waterfall plots of patients who received either enzalutamide or abiraterone as the first novel androgen receptortargeted agent are shown in Figure 1A and B, respectively. The percent changes in serum PSA levels relative to the baseline $(\%$ PSA change) between flutamide effective and flutamide ineffective groups following enzalutamide or abiraterone therapies are shown in Figure 1C and D, respectively. Among the patients who used enzalutamide as the first novel androgen receptor-targeted agent, the flutamide effective group (enzaflutamide effective group) had a significantly higher \% PSA change as compared to the flutamide ineffective group (enzaflutamide ineffective group) $(p=0.039)$. The clinical characteristics of the patients who received enzalutamide following alternative anti-androgen therapy with flutamide are shown in Table II. Lymph node metastasis was significantly higher in the enza-flutamide effective group as compared to the enza-flutamide ineffective group.

The log-rank test showed that the enza-flutamide effective group had a significantly higher PSA-PFS survival rate as compared to the enza-flutamide ineffective group $(p=0.016)$. On the other hand, no differences in the PSA-PFS rate of time following CRPC diagnosis among the enza-flutamide effective group, the enza-flutamide ineffective group, and patients who did not receive flutamide (enza-flutamide no use group) were 
(A) Enzalutamide

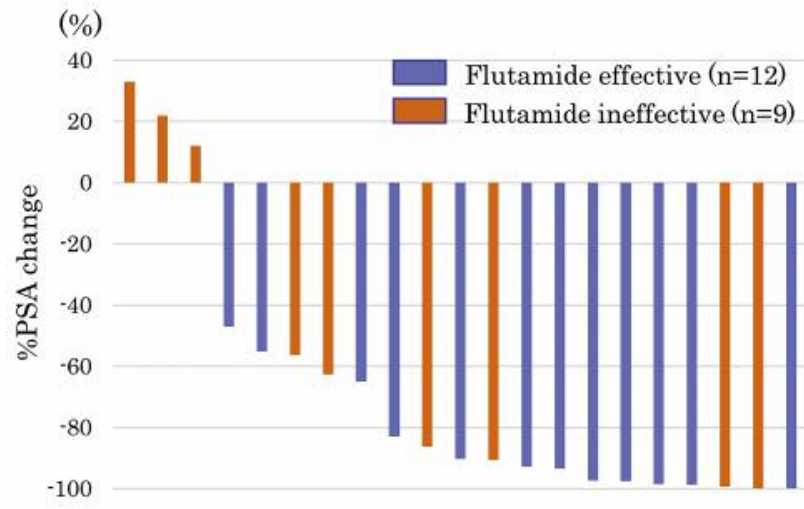

(C) Enzalutamide

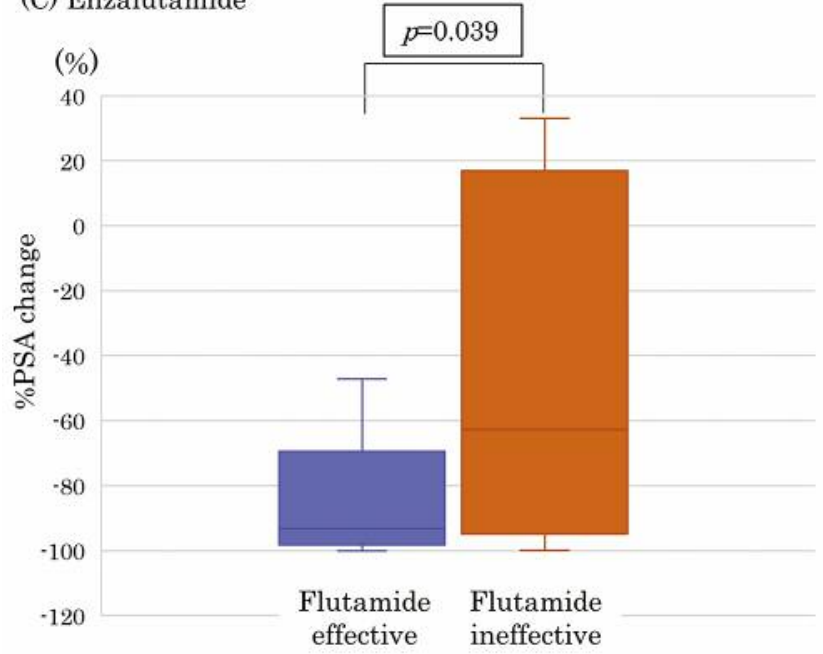

(B) Abiraterone

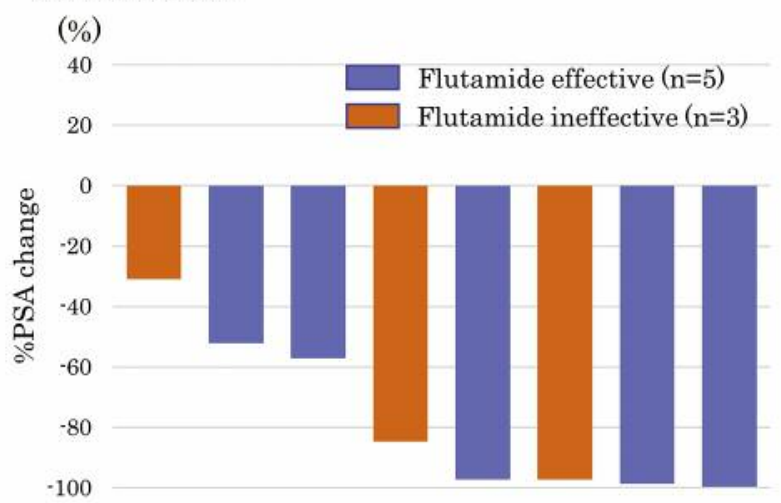

(D) Abiraterone

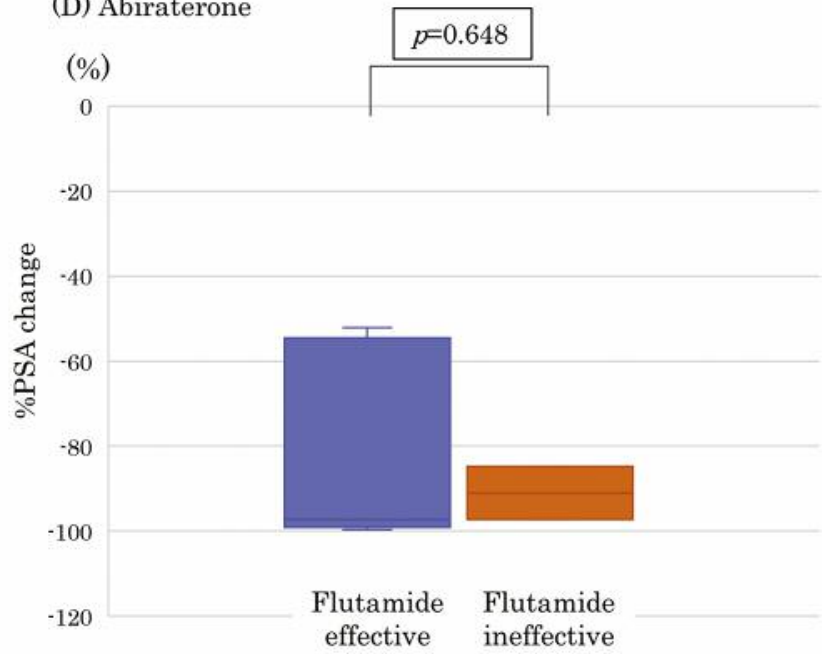

Figure 1. Maximum percent changes in serum PSA levels relative to the baseline (\% PSA change) during therapy with novel androgen receptortargeted agents (enzalutamide or abiraterone). Waterfall plots in patients who received enzalutamide $(A)$ or abiraterone $(B)$. Maximum percent change in serum PSA relative to the baseline between flutamide effective and flutamide ineffective groups following subsequent treatment with enzalutamide $(C)$ or abiraterone $(D)$.

found before initiating enzalutamide therapy (enza-flutamide effective group versus enza-flutamide no use group, $p=0.314$, enza-flutamide ineffective group versus enza-flutamide no use group, $p=0.256$ ). The multivariate analysis showed that flutamide efficacy was significantly associated with PSA-PFS in patients who were administered with enzalutamide as novel androgen receptor-targeted agent [hazard ratio $(\mathrm{HR})=7.36,95 \%$ confidence interval $(\mathrm{CI})=1.4-38.71, p=0.018]$ (Table III).

\section{Discussion}

Until docetaxel was introduced in 2004, there were no drugs that could improve the overall survival (OS) of patients who progressed to CRPC (16). Even after docetaxel was introduced, the efficacy of alternative anti-androgen therapy with flutamide has been reported prior to docetaxel treatment in clinical settings (9-11). After 2012, novel androgen receptor-targeted agents, such as enzalutamide and abiraterone, which demonstrated significantly improved OS in randomized clinical trials targeting both docetaxel-naïve and docetaxel-treated patients, were introduced and were frequently used as second-line therapies in CRPC patients prior to administration of docetaxel (4-8). Based on the results of randomized clinical trials, it was suggested that it is better practice to use the novel androgen receptor-targeted agents early in CRPC. These agents, however, have several adverse effects, with enzalutamide possibly causing fatigue and abiraterone inducing liver dysfunction and steroidrelated adverse effects (4-7). Considering these facts, it is important to re-evaluate the efficacy of alternative antiandrogen therapy using flutamide and to examine whether the therapeutic effects of alternative anti-androgen therapy 
Table II. Clinical characteristics of patients who received enzalutamide following alternative anti-androgen therapy with flutamide.

\begin{tabular}{|c|c|c|c|}
\hline & \multicolumn{2}{|c|}{ PSA decline compared to baseline } & \multirow[b]{2}{*}{$p$-Value } \\
\hline & Effective $(\mathrm{n}=12)$ & Not effective $(n=9)$ & \\
\hline Median Age (years, range) & $74.5(60-90)$ & $80.0(72-91)$ & 0.054 \\
\hline Median initial PSA (ng/ml, range) & $243.7(20.8-5066.0)$ & $233.7(50.0-7139.7)$ & 1.000 \\
\hline Biopsy Gleason score $(\mathrm{n}, \%)$ & & & 1.000 \\
\hline$\leq 7$ & $3(25.0)$ & $2(22.2)$ & \\
\hline $8-10$ & $7(58.3)$ & $5(55.6)$ & \\
\hline Unknown & $2(16.7)$ & $2(22.2)$ & \\
\hline Clinical T stage (n, \%) & & 0.486 & \\
\hline $\mathrm{T} 1-\mathrm{T} 2$ & $2(16.7)$ & - & \\
\hline$\geq \mathrm{T} 3 \mathrm{a}$ & $10(83.3)$ & $9(100.0)$ & \\
\hline $\mathrm{N}$ positive (lymph node metastasis) (n, \%) & $3(25.0)$ & $5(55.6)$ & 0.043 \\
\hline M positive (n, \%) & $10(83.3)$ & $4(44.4)$ & 0.569 \\
\hline Median PSA nadir during initial MAB (ng/ml, range) & $0.16(0.0-16.4)$ & $1.41(0.1-7.4)$ & 0.072 \\
\hline Median duration of initial MAB (months, range) & $101(71.6)$ & $65(65.0)$ & 0.972 \\
\hline $\begin{array}{l}\text { Enzalutamide effective (PSA decline compared to } \\
\text { baseline of enzalutamide induction) (n, \%) }\end{array}$ & $12(100.0)$ & $6(66.7)$ & 0.063 \\
\hline
\end{tabular}

PSA: Prostate-specific antigen; MAB: maximum androgen blockade.

Table III. Univariate and multivariate logistic regression analyses for PSA-PFS prediction with enzalutamide therapy in patients receiving alternative anti-androgen therapy with flutamide.

\begin{tabular}{|c|c|c|c|c|c|}
\hline & & \multirow{2}{*}{$\frac{\text { Univariate }}{p \text {-Value }}$} & \multicolumn{2}{|c|}{ Multivariate } & \multirow[b]{2}{*}{$p$-Value } \\
\hline & & & HR & $95 \% \mathrm{CI}$ & \\
\hline Age (years) & $\geq 70$ vs. $<70$ & 0.912 & & & \\
\hline Initial PSA (ng/ml) & $\geq 100$ vs. $<100$ & 0.602 & & & \\
\hline PSA (novel AR-targeted agent induction) (ng/ml) & $\geq 20$ vs. $<20$ & 0.790 & & & \\
\hline Biopsy Gleason score & $8-10 v s . \leq 7$ & 0.400 & & & \\
\hline Clinical T Stage & $\geq \mathrm{cT} 3$ vs. $<\mathrm{cT} 3$ & 0.290 & & & \\
\hline $\mathrm{N}$ positive (Lymph node meta) & $(+) v s .(-)$ & 0.007 & & & 0.126 \\
\hline M positive & $(+) v s .(-)$ & 0.872 & & & \\
\hline PSA nadir during initial MAB (ng/ml) & $\geq 2.0 \mathrm{vs} .<2.0$ & 0.158 & & & 0.285 \\
\hline Duration of initial MAB, month & $\geq 12$ vs. $<12$ & 0.525 & & & \\
\hline Flutamide effective (PSA decline compared to baseline of flutamide induction) & $(+) v s .(-)$ & 0.016 & 7.36 & $1.4-38.71$ & 0.018 \\
\hline
\end{tabular}

PSA: Prostate-specific antigen; MAB: maximum androgen blockade; HR: hazard ratio.

using flutamide affect the efficacy of novel androgen receptor-targeted agents. Only a few reports have evaluated the relationship between the therapeutic effects of alternative anti-androgen therapy using flutamide and the subsequent treatment effect of novel androgen receptor-targeted agents $(12,13)$. In the present study, we reviewed the clinical characteristics of 79 patients and examined the clinical benefits of flutamide as an alternative anti-androgen agent and as an effective predictor of novel androgen receptortargeted agents.

The enza-flutamide effective group showed significantly higher PSA-PFS survival rate as compared to the enza- flutamide ineffective group. Additionally, flutamide efficacy was significantly associated with a high PSA-PFS rate in patients who were administered with enzalutamide as a novel androgen receptor-targeted agent. On the other hand, no differences in the PSA-PFS rate following CRPC diagnosis were noted among the enza-flutamide effective group, the enza-flutamide ineffective group, and the enza-flutamide no use group. Taken together, these data suggest that it is important to evaluate alternative anti-androgen therapy using flutamide as a second line therapy for CRPC. Furthermore, patients showing a good response to flutamide following initial MAB using bicalutamide might show a good PSA- 
(A)

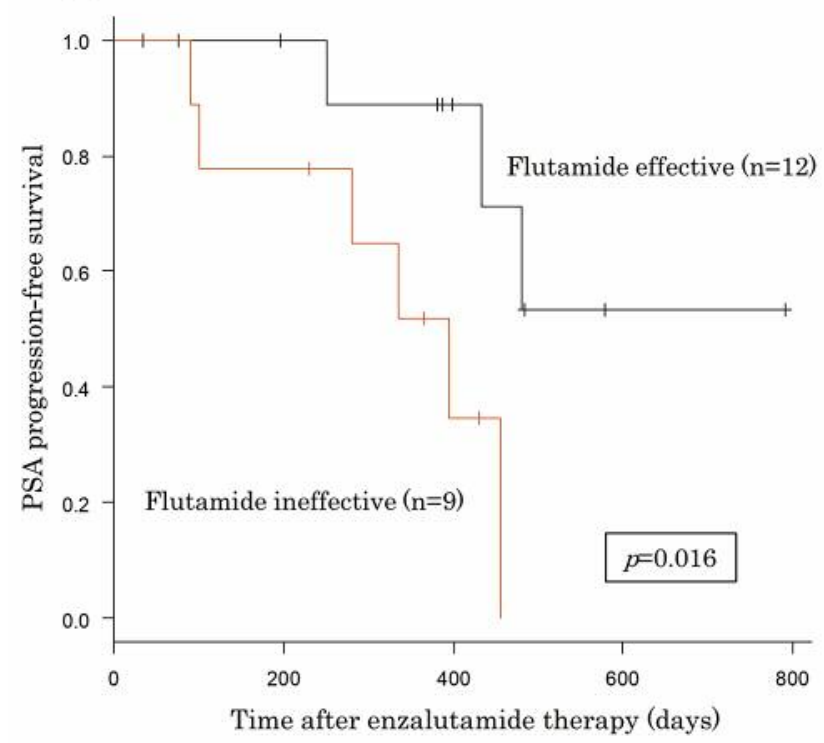

(B)

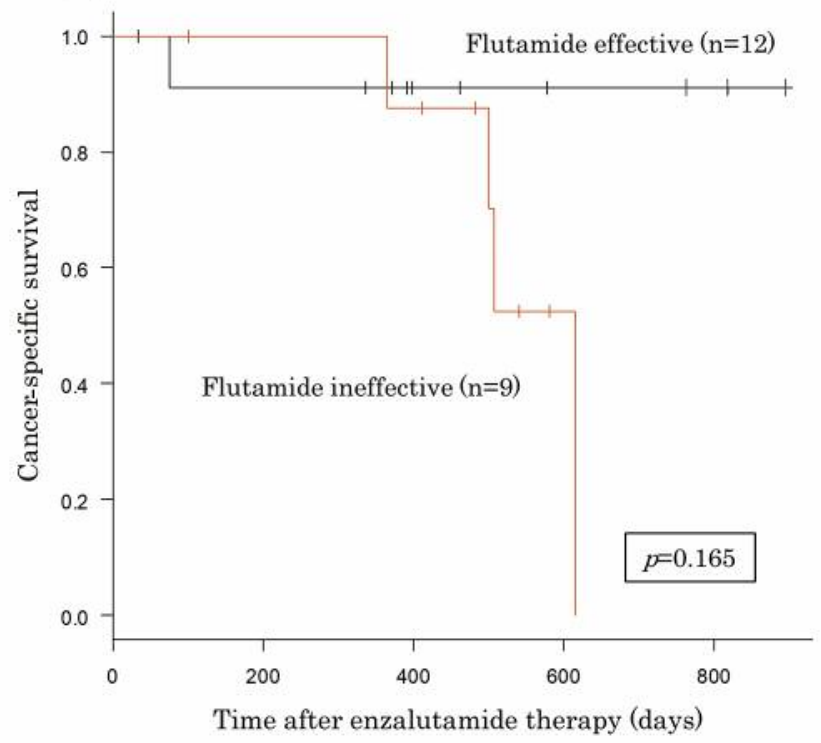

Figure 2. Comparisons of (A) PSA-PFS and (B) CSS rates between enza-flutamide effective and enza-flutamide ineffective groups following induction of enzalutamide.

(A)

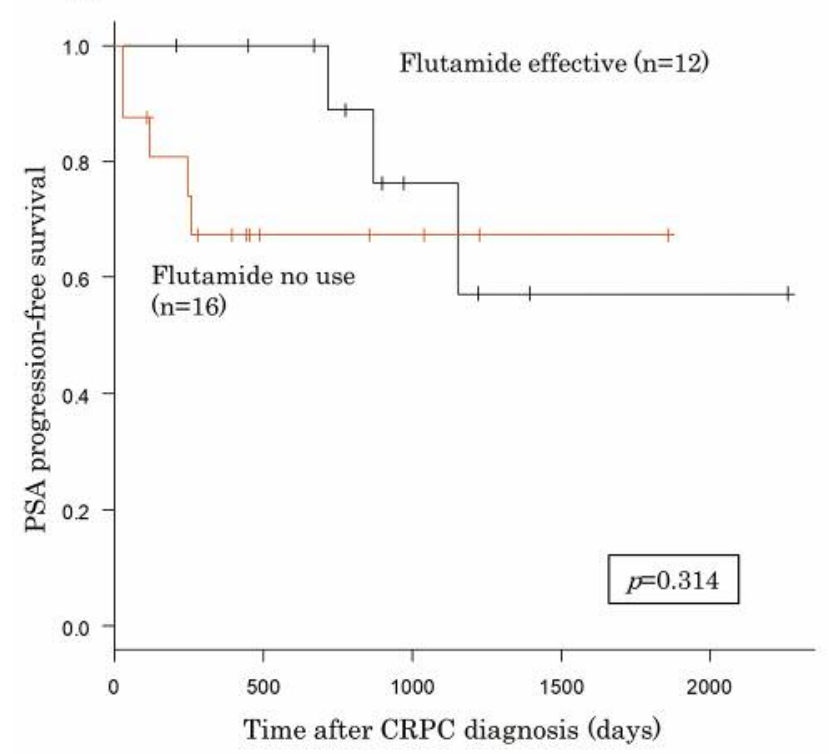

(B)

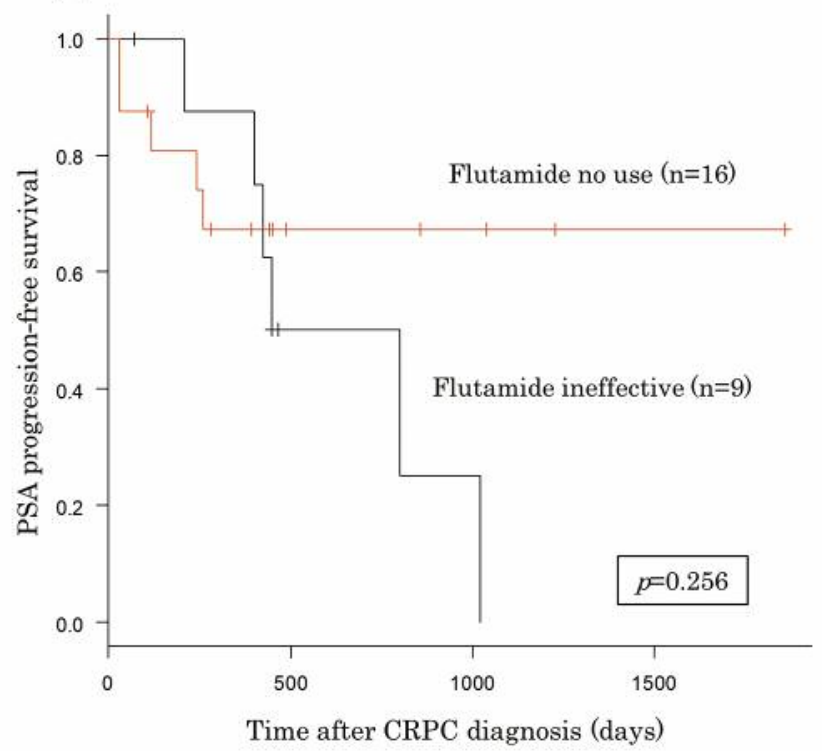

Figure 3. Comparison of PSA-PFS rate (A) between enza-flutamide effective and enza-flutamide no-use groups, and (B) between enza-flutamide ineffective and enza-flutamide no-use groups following diagnosis of CRPC.

PFS rate when subsequent novel androgen receptor-targeted therapy, using enzalutamide, is offered.

There are several reasons why the therapeutic effects of alternative anti-androgen therapy using flutamide can be a predictor of PSA-PFS of novel androgen receptor-targeted therapy. First, it is reported that the period of initial MAB therapy using bicalutamide is longer in patients who respond to alternative anti-androgen therapy using flutamide as compared to those who do not show such a response (11), although there was no obvious difference in the results of this study between the two groups (data not shown). Furthermore, another study has reported that prior long-term response to 
antiandrogen deprivation for $\geq 12$ months was a good predictor of enzalutamide response (17), similar to what is reported by Momozono et al., who used flutamide (11). Secondly, it is reported that flutamide inhibits CYP17 (18), similar to abiraterone acetate inhibiting CYP17A (19). It may be possible to observe a cross-resistance between these two agents.

Nakai et al., have reported that patients using abiraterone as the first novel androgen receptor targeted agent and showing a good response to flutamide therapy following initial MAB using bicalutamide therapy, had a significantly higher PSA-PFS rate and $\%$ PSA change compared to those without such response. However, multivariate analysis for the predictive factor of PSAPFS was not performed in this study (12). From the above results, it was considered that the efficacy of alternative antiandrogen therapy using flutamide in CRPC patients could be a predictor of subsequent enzalutamide therapy.

There exist some limitations to our present study. Firstly, this study was retrospective and not randomized. We did not mention the type of treatment following the first novel androgen receptortargeted therapy. Secondly, the number of target patients was small and the observation period was short. Thirdly, some patients with aggressive disease were not included in this study because docetaxel was administered prior to administration of the novel androgen receptor-targeted agents. A large number of prospective studies to elucidate the mechanism of relationships between alternative anti-androgen therapy using flutamide and enzalutamide is required in the future.

In conclusion, alternative anti-androgen therapy with flutamide can be administered as a second-line therapy for CRPC. Furthermore, patients showing a good response to alternative anti-androgen therapy using flutamide as secondline therapy following initial MAB may be able to achieve satisfactory benefits in terms of PSA-PFS rate with subsequent enzalutamide therapy.

\section{Conflicts of Interest}

The Authors declare no conflict of interest.

\section{Authors' Contributions}

NY designed and performed the research and collected and analyzed the data and wrote the manuscript. SM designed and performed research, collected data, and assisted in the preparation of the manuscript. All other authors contributed to data collection and interpretation, and critically reviewed the manuscript. All authors approved the manuscript and agreed to be accountable for all aspects of the work in ensuring that questions related to the accuracy or integrity of any part of the work were appropriately investigated and resolved.

\section{Acknowledgements}

The Authors would like to thank the doctors of satellite hospitals for their contribution in data collection.

\section{References}

1 Siegel R, Ma J, Zou Z and Jemal A: Cancer statistics. CA Cancer J Clin 64(1): 9-29, 2014. PMID: 24399786. DOI: 10.3322/ caac. 21208

2 Ito K: Prostate cancer in Asian men. Nat Rev Urol 11(4): 197212, 2014. PMID: 24595118. DOI: 10.1038/nrurol.2014.42

3 Harris WP, Mostaghel EA, Nelson PS and Montgomery B: Androgen deprivation therapy: progress in understanding mechanisms of resistance and optimizing androgen depletion. Nat Clin Pract Urol 6(2): 76-85, 2009. PMID: 19198621. DOI: 10.1038/ncpuro1296

4 Beer TM, Armstrong AJ, Rathkopf DE, Loriot Y, Sternberg CN, Higano CS, Iversen P, Bhattacharya S, Carles J, Chowdhury S, Davis ID, de Bono JS, Evans CP, Fizazi K, Joshua AM, Kim CS, Kimura G, Mainwaring P, Mansbach H, Miller K, Noonberg SB, Perabo F, Phung D, Saad F, Scher HI, Taplin ME, Venner PM and Tombal B; PREVAIL Investigators: Enzalutamide in metastatic prostate cancer before chemotherapy. N Engl J Med 371(5): 424-433, 2014. PMID: 24881730. DOI: 10.1056/NEJM oa 1405095

5 Ryan CJ, Smith MR, de Bono JS, Molina A, Logothetis CJ, de Souza P, Fizazi K, Mainwaring P, Piulats JM, Ng S, Carles J, Mulders PF, Basch E, Small EJ, Saad F, Schrijvers D, Van Poppel H, Mukherjee SD, Suttmann H, Gerritsen WR, Flaig TW, George DJ, Yu EY, Efstathiou E, Pantuck A, Winquist E, Higano CS, Taplin ME, Park Y, Kheoh T, Griffin T, Scher HI and Rathkopf DE; COU-AA-302 Investigators: Abiraterone in metastatic prostate cancer without previous chemotherapy. N Engl J Med 368(2): 138-148, 2013. PMID: 23228172. DOI: 10.1056/NEJMoa1209096

6 Scher HI, Fizazi K, Saad F, Taplin ME, Sternberg CN, Miller K, de Wit R, Mulders P, Chi KN, Shore ND, Armstrong AJ, Flaig TW, Fléchon A, Mainwaring P, Fleming M, Hainsworth JD, Hirmand M, Selby B, Seely L and de Bono JS; AFFIRM Investigators: Increased survival with enzalutamide in prostate cancer after chemotherapy. N Engl J Med 367(13): 1187-1197, 2012. PMID: 22894553. DOI: 10.1056/NEJMoa1207506

7 de Bono JS, Logothetis CJ, Molina A, Fizazi K, North S, Chu L, Chi KN, Jones RJ, Goodman OB Jr., Saad F, Staffurth JN, Mainwaring P, Harland S, Flaig TW, Hutson TE, Cheng T, Patterson H, Hainsworth JD, Ryan CJ, Sternberg CN, Ellard SL, Fléchon A, Saleh M, Scholz M, Efstathiou E, Zivi A, Bianchini D, Loriot Y, Chieffo N, Kheoh T, Haqq CM and Scher HI; COUAA-301 Investigators: Abiraterone and increased survival in metastatic prostate cancer. N Engl J Med 364(21): 1995-2005, 2011. PMID: 21612468. DOI: 10.1056/NEJMoa1014618

8 Saito $\mathrm{K}$ and Fujii Y: Antitumor activity and safety of enzalutamide after abiraterone acetate: Seeking the optimal treatment sequence for castration-resistant prostate cancer patients. Eur Urol 74(1): 46-47, 2018. PMID: 29066029. DOI: 10.1016/j.eururo.2017.09.038

9 Suzuki H, Okihara K, Miyake H, Fujisawa M, Miyoshi S, Matsumoto T, Fujii M, Takihana Y, Usui T, Matsuda T, Ozono S, Kumon H, Ichikawa T and Miki T; Nonsteroidal Antiandrogen Sequential Alternation for Prostate Cancer Study Group: Alternative nonsteroidal antiandrogen therapy for advanced prostate cancer that relapsed after initial maximum androgen blockade. J Urol 180(3): 921-927, 2008. PMID: 18635218. DOI: 10.1016/j.juro.2008.05.045 
10 Okegawa $\mathrm{T}$, Nutahara $\mathrm{K}$ and Higashihara E: Alternative antiandrogen therapy in patients with castration-resistant prostate cancer: A single-center experience. Int J Urol 17(11): 950-955, 2010. PMID: 20807265. DOI: 10.1111/j.1442-2042.2010.02 620.x

11 Momozono H, Miyake H, Tei H, Harada K and Fujisawa M: Clinical outcomes of anti-androgen withdrawal and subsequent alternative anti-androgen therapy for advanced prostate cancer following failure of initial maximum androgen blockade. Mol Clin Oncol 4(5): 839-844, 2016. PMID: 27123292. DOI: 10.3892/ mco. 2016.817

12 Nakai Y, Tanaka N, Miyake M, Inoue T, Anai S and Fujimoto $\mathrm{K}$ : Response to flutamide, as second line therapy after bicalutamide, predicts efficacy of abiraterone, not that of enzalutamide. BMC Res Notes 11(1): 342, 2018. PMID: 29843816. DOI: 10.1186/s13104-018-3453-z

13 Iguchi T, Tamada S, Kato M, Yasuda S, Otoshi T, Hamada K, Yamasaki T and Nakatani T: Enzalutamide versus flutamide for castration-resistant prostate cancer after combined androgen blockade therapy with bicalutamide: a retrospective study. Int J Clin Oncol, 2019. PMID: 30741370. DOI: 10.1007/s10147-01901413-1

14 Sher HI, Halabi S, Tannock I, Morris M, Sternberg CN, Carducci MA, Eisenberger MA, Higano C, Bubley GJ, Dreicer R, Petrylak D, Kantoff P, Basch E, Kelly WK, Figg WD, Small EJ, Beer TM, Wilding G, Martin A and Hussain M; Prostate Cancer Clinical Trials Working Group: Design and end points of clinical trials for patients with progressive prostate cancer and castrate levels of testosterone: recommendations of the Prostate Cancer Clinical Trials Working Group. J Clin Oncol 26(7): 11481159, 2008. PMID: 18309951. DOI: 10.1200/JCO.2007.12.4487

15 Kanda Y: Investigation of the freely available easy-to-use software 'EZR' for medical statistics. Bone Marrow Transplant 48(3): 452458, 2013. PMID: 23208313. DOI: 10.1038/ bmt.2012.244
16 Tannock IF, de Wit R, Berry WR, Horti J, Pluzanska A, Chi KN, Oudard S, Theodore C, James ND, Turesson I, Rosenthal MA and Eisenberger MA; TAX 327 Investigators: Docetaxel plus prednisone or mitoxantrone plus prednisone for advanced prostate cancer. N Engl J Med 351(15): 1502-1512, 2004. PMID: 15470213. DOI: 10.1056/NEJMoa040720

17 Loriot Y, Eymard JC, Patrikidou A, Ileana E, Massard C, Albiges L, Di Palma M, Escudier B and Fizazi K: Prior long response to androgen deprivation predicts response to next-generation androgen receptor axis targeted drugs in castration-resistant prostate cancer. Eur J Cancer 51(14): 1946-1952, 2015. PMID: 26208462. DOI: 10.1016/j.ejca.2015.06.128

18 Ayub M and Levell MJ: Suppression of plasma androgens by the antiandrogen flutamide in prostate cancer patients treated with Zoladex, a GnRH analogue. Clin Endocrinol 32(3): 329-339, 1990. PMID: 2140542. DOI: 10.1111/j.1365-2265.1990.tb00 874.x

19 Taplin ME, Montgomery B, Logothetis CJ, Bubley GJ, Richie JP, Dalkin BL, Sanda MG, Davis JW, Loda M, True LD, Troncoso P, Ye H, Lis RT, Marck BT, Matsumoto AM, Balk SP, Mostaghel EA, Penning TM, Nelson PS, Xie W, Jiang Z, Haqq CM, Tamae D, Tran N, Peng W, Kheoh T, Molina A and Kantoff PW: Intense androgen-deprivation therapy with abiraterone acetate plus leuprolide acetate in patients with localized highrisk prostate cancer: results of a randomized phase 2 neoadjuvant study. J Clin Oncol 32(33): 3705-3715, 2014. PMID: 25311217. DOI: $10.1200 / J C O .2013 .53 .4578$
Received May 17, 2019

Revised June 16, 2019

Accepted June 18, 2019 